\title{
THE THREE LEGGED SYSTEM OF ORGANISATIONAL INTEERITY
}

\author{
Gyula PULAY ${ }^{\text {a,* }}$ \\ a) Miskolc University, Hungary and State Audit Office of Hungary
}

Please cite this article as:

Pulay, G., 2017. The three legged system of organisational integrity. Review of Economic Studies and Research Virgil Madgearu, 10(2), pp.159-175.

doi: 10.24193/RVM.2017.10.14.
Article History:

Received: 30 August 2017 Accepted: 30 October 2017

\begin{abstract}
Public organisation with mature integrity systems are resistant to the misconduct of their own employees, such as corruption and other misuses of public property. This article argues that legality, legitimacy and legacy are the three legs of a solid system of organisational integrity. Legality since compliance with the legal rules is the precondition of integrity. Organisations moving from legality to legitimacy build their inner regulations on the values and basic principle of the laws and not on their specific provisions only. Organisations with integrity try to leave legacy to their successors, valuable fortune to the future generation, they try to fulfil their mission and help their employees to realize their vocation. The endeavour to go beyond legality to legitimacy and create legacy helps organisations to exceed the level of compliance and reach the level of integrity.
\end{abstract}

Key words: management control; corruption prevention; integrity

JEL Classification: $\mathrm{H}_{83} \mathrm{O}$; K4; K42O

(C) 2017 Alma Mater Publishing House. All rights reserved.

* Corresponding author. E-mail address: szvpulay@uni-miskolc.hu. 


\section{References}

1. Lander, N. and Nahon, D., 2006. The integrity model of existential psychotherapy in working with the 'Difficult Patient'. New York: Routledge.

2. Maesschalck, J., 2004. Approaches to ethics management in the public sector: a proposed extension of the compliancy-integrity continuum. Public Integrity, 7(1), pp.21-41.

3. Menzel, D.C., 2012. Ethics management for public administrators: leading and building organisations of integrity. New York: Routledge.

4. Ouchi, W.G., 1980. Markets, bureaucracies and clans. Administrative Science Quarterly, 25(1), pp.129-141.

5. Paine, L.S., 1994. Managing for organizational integrity. Harvard Business Review March-April, 72(2), pp.106-118.

6. Pulay, G., 2014. Preventing corruption by strengthening organisational inetgrity, Public Finance Quarterly, 59(2), pp. 151-166.

7. Schein, E.H., 1984. Coming to a new awareness of organizational culture. Sloan Management Review, 25(2), pp.3-16.

8. Tyler, T., Dienhart, J. and Thomas, T., 2008. The ethical commitment to compliance: building value-based cultures. California Management Review, 50(2), pp. 31-51.

9. Verhezen, P., 2007. The (ir)relevance of integrity in organisations? A corporate governanceperspective. In World Ethics Forum Conference Proceedings. Availableat: https://www.researchgate.net/profile/Peter_Verhezen/publication/264855438_ The_irrelevance_of_Accountability_Responsibility_in_Organizations_A_ corporate_governance_perspective/links/5412fc55ocf2fa878ad3cd6c/ The-irrelevance-of-Accountability-Responsibility-in-Organizations-A-corporategovernance-perspective.pdf.

10. Verhezen, P., 2010. Giving Voice in a Culture of Silence - From a culture of compliance to a culture of integrity. Journal of Business Ethics, 96(2), pp 187-206. 